\title{
Preliminary study of Illex coindetii and Todaropsis eblanae (Cephalopoda:Ommastrephidae) in northern Spanish
}

\section{Atlantic waters}

Angel F. Gonzalez*, Mario Rasero, Angel Guerra

Instituto de Investigaciones Marinas (CSIC), Eduardo Cabello 6, 36208 Vigo, Spain

*Corresponding author.

\begin{abstract}
Post-recruit Illex coindetii and Todaropsis eblanae were collected from the fishery on the Galician shelf between November 1991 and April 1992. Maturity was assessed using a maturity scale. Sex ratios, monthly length frequencies distributions and the relationship between dorsal mantle length (ML) and body weight (BW) of both species were determined. Illex coindetii males were more precocious than females. Mature males and females were found during the entire period sampled, although a considerable maturation peak in April was observed. Todaropsis eblanae males were more precocious than females. The spawning season starts in February and extends at least until April. No distinction is made between the two species of squid in landing statistics. The range of the northern Spanish Atlantic landings from 1980 to 1991 was 490-2352 t.
\end{abstract}

Keywords: 1llex coindetti; Population structure; Spain; Todaropsis eblanae

\section{Introduction}

Illex coindetii (Vérany, 1837) has been recorded in the entire Mediterranean Sea, in the eastern Atlantic from the Bristol Channel to Namibia, and in the western Atlantic from the Caribbean Sea, to the Gulf of Mexico and the Straits of Florida (Roper et al., 1969; Lu, 1973; Roper et al., 1984; Nesis, 1987). Illex coindetii inhabits a wide range of depths from 20 to $1100 \mathrm{~m}$, being common between 100 and $400 \mathrm{~m}$ (Guerra, 1992). Spawning occurs throughout the year (Sanchez, 1981; Ch.M. Nigmatullin, personal communication, 1993). 
Todaropsis eblanae (Ball, 1841) is widely distributed in the eastern Atlantic and Mediterranean Sea, between $60^{\circ} \mathrm{N}$ and $36^{\circ} \mathrm{S}$ (Roper et al., 1984). It has been also recorded from the southwestern Indian Ocean (Nesis, 1979) and Australian waters (Lu, 1982). Data on the life history of the species are very scarce. It is a relatively small animal, with a maximum recorded mantle length of $270 \mathrm{~mm}$ (Degner, 1925) and it lives on or near the bottom in depths of about 20-700 m (Clarke, 1966). Mangold-Wirz (1963) indicated that the spawning period of T. eblanae extends from March to November in the Mediterranean Sea. Joy (1989) studied some biological aspects of the species in Shetland waters and fecundity was analysed by Hastie et al. (1994) in Scottish waters.

It is important to remark that the fishery for Illex coindetii in Galician waters started a few years ago. Before 1983, Todaropsis eblanae was the only relatively abundant ommastrephid squid in these waters while I. coindetii was almost absent in the fishing hauls of both commercial trawlers and research vessels. Since 1983, the abundance of I. coindetii began to increase. Presently both species have similar landing levels, although with great annual fluctuations (Gonzalez et al., 1992). Illex coindetii and T. eblanae are the only significantly abundant ommastrephid squid in the Galician fishery. No distinction between the two species is made in the landing statistics.

This paper presents preliminary results on the biology of I coindetii and T. eblanae off the northern Spanish Atlantic coast (Galician waters, Fig. 1), together with the Galician annual landing statistics during the period 1980-1991. It constitutes the first contribution to the knowledge of the life cycle and fishery of both species in the Spanish Atlantic waters.

\section{Materials and methods}

Samples of lllex coindetii and Todaropsis eblanae were obtained from commercial landings in two ports in the north of Galicia (Burela and Celeiro). Additional samples of I. coindetii were obtained in one port in the south of Galicia (Ribeira) (Fig. 1). A total of 2911 I. coindetii and 1266 T. eblanae in six samples were examined from November 1991 to April 1992. Samples were randomly collected from both otter and pair trawlers 
where squid is taken as a by-catch. Samples were frozen at $-20{ }^{\circ} \mathrm{C}$ until the time of processing.

Basic biological data were collected after the samples were thawed at room temperature. The squid were sexed and the total body weight (BW) was obtained. The dorsal mantle length (ML) was measured to the nearest millimetre. The maturity stage was assessed by a maturity scale of five stages for males and six stages for females, according to the universal maturity scale (Lipinski, 1979), but combining Lipinski's stages 1 and 2 for males as stage 1 .

The data set for the fishery is derived from landings of short-finned squid at Galician ports by trawlers fishing on the Galician continental shelf from 1980 to 1991. This information was obtained from official statistics of the fishermen's cooperatives.

\section{Results}

\subsection{Maturation}

Table 1 shows the percentage of I. coindetii males and females in each maturity stage and ML class. Illex coindetii males are more precocious than females. The smallest mature male measured $93 \mathrm{~mm}$, while the smallest mature female measured $148 \mathrm{~mm}$. The size of the mature males ranged from 93 to $279 \mathrm{~mm} \mathrm{ML}$, while the size of the mature females ranged from 148 to $379 \mathrm{~mm}$ ML. Spent males were not found, and very few spent females were caught in the samples. The size at first maturity (ML at which $50 \%$ of the specimens were mature in the population) was $160-179 \mathrm{~mm}$ for males and 200-219 mm for females.

Table 2 shows the monthly percentage of I. coindetii males and females in each maturity stage. During the sampled period, mature males of I. coindetii were more abundant than mature females. The relatively high abundance of mature females in April suggests a peak of maturation, even though the spawning season extends throughout the period sampled. 
Table 3 shows the percentage of $\mathrm{T}$. eblanae males and females in each maturity stage and ML class. Todaropsis eblanae males are more precocious than females. The smallest mature male measured $104 \mathrm{~mm}$ ML, while the smallest female was $140 \mathrm{~mm}$ ML. The size of the mature males ranged from 104 to $169 \mathrm{~mm} \mathrm{ML}$, while the size of the mature females ranged from 140 to $219 \mathrm{~mm}$ ML. Spent males (stage 5) were found, while very few spent females were caught in the samples. The size at first maturity was 130-149 mm ML for males, and 180-199 mm for females.

Table 4 shows the monthly percentage of T. eblanae males and females in each maturity stage. These results suggest that the spawning season of T. eblanae in this area starts in February, extending at least until April.

\subsection{Sex ratio}

Table 5 shows the monthly variation of the number of males and females for I. coindetii. The monthly sex ratios of I. coindetii differ significantly $(\mathrm{P}<0.05)$ from $1: 1$ in November and December. The pooled sex ratio of the species was not significantly different from 1:1 $(\mathrm{P}<0.05)$.

Table 6 shows the monthly variation of the number of males and females for Todaropsis eblanae. The monthly $\mathrm{T}$. eblanae sex ratios were not significantly different from the expected 1:1 ratio $(\mathrm{P}<0.05)$ during the period sampled except in April. The pooled sex ratio of the species was significantly different from $1: 1(\mathrm{P}<0.05)$.

\subsection{Length frequencies}

Monthly length-frequency histograms for male and female I. coindetii are illustrated in Fig. 2. Fig. 3 shows the monthly length-frequency distributions of T. eblanae. Females reach a larger size than males in both species. Modal progressions can be observed in some of the data, although it is difficult to identify individual microcohorts. The presence of small I. coindetii and T. eblanae $(\mathrm{ML}<100 \mathrm{~mm})$ throughout the period sampled represents recruitment.

\subsection{Length-weight relationships}


The ML and BW relationships for male and female I. coindetii are

$$
\begin{aligned}
& \mathrm{W}=0.00001 \mathrm{ML}^{3268}\left(\mathrm{r}^{2}=0.885, \mathrm{~N}=1412\right) \text { for males } \\
& \mathrm{W}=0.0000423 \mathrm{ML}^{2883}\left(\mathrm{r}^{2}=0.902, \mathrm{~N}=1365\right) \text { for females. }
\end{aligned}
$$

The slope (b) was significantly higher in males than in females $(\mathrm{P}<0.05)$. The relationships between $\mathrm{ML}$ and $\mathrm{B} \mathrm{W}$ of $\mathrm{T}$. eblanae are

$$
\mathrm{W}=0.00001066 \mathrm{ML}^{2917}\left(\mathrm{r}^{2}=0.971, \mathrm{~N}=684\right)
$$

for males and

$$
\mathrm{W}=0.0003162 \mathrm{ML}^{2671}\left(\mathrm{r}^{2}=0.978, \mathrm{~N}=582\right)
$$

for females.

The slope (b) was significantly higher in males than in females $(\mathrm{P}<0.05)$.

\subsection{The fishery}

Illex coindetii and Todaropsis eblanae are the only ommastrephid squid with significant presence in the Galician trawl fishery and they are caught as a by catch. The target species of this fishery are mostly hake and blue whiting. Vessels working in this fishery are otter and pair trawlers. In 1992 the number of trawlers was 171 (Xunta de Galicia, 1993). The main ports in this area are Burela, Celeiro, Coruña, Ribeira, Marin and Vigo (Fig. 1). The vessels are steel and wooden trawlers, 25-30 m long. They average $155 \mathrm{t}$, with an average propulsion power of $379 \mathrm{HP}$ and crews of seven to nine. Fishing is carded out on local fishing grounds from 100 to $350 \mathrm{~m}$ depth. These vessels do not have freezing facilities, so they return to port daily, landing fresh fish in the markets where it is sold every evening in public auction sales. No distinction is made between the two species of squid, both of which are used for human consumption.

Fig. 4 shows the monthly total landings of ommastrephid squid for the period 19861991. Fig. 5 illustrates the annual landings and values of the catches from 1980 to 1991. Total landings of these species ranged from $490 \mathrm{t}$ in 1985 to $2352 \mathrm{t}$ in 1987 . The price varied from 94.2 ptas (pesetas) $\mathrm{kg}^{-1}$ in 1987 to $156.2 \mathrm{ptas} \mathrm{kg}^{-1}$ in 1990. The lowest landings were in summer, while the highest landings generally occurred in spring and autumn (Fig. 4). 


\section{Discussion}

From the mature individuals observed in I. coindetii it is concluded that males mature at a smaller size than females. The size range at which mature males and females were found in Galician waters is similar to that observed by Mangold-Wirz (1963) and Sanchez (1981) in the western Mediterranean and Coelho and Borges (1982) off the Portuguese coast.

Mature males and females of I. coindetii were found in both areas during the entire sampling period, but a peak of maturation was observed in April. Further studies are necessary in order to test whether the spawning period of this species extends until October-November as reported in other areas by Mangold-Wirz (1963), Burukovski et al. (1979), Sanchez (1981) and Coelho and Borges (1982).

The sex ratio observed off the Galician coast in I. coindetii is very near to the expected $1: 1$, although it varies monthly. Males were more abundant than females in the sampled period. This agrees with observations by Jereb and Ragonese (1991) in the Sicilian Channel, Nigmatullin (personal communication, 1993) in West African waters and Sanchez (1981) in the Catalan Sea. It is possible that the differences found between male and female abundance (sex ratio) could be due to catch bias rather than to population structure. Small specimens of I. coindetii (less than $100 \mathrm{~mm} \mathrm{ML}$ ) were found during the whole period sampied. This observation indicates a continuous recruitment from November to April.

Illex coindetii length-weight relationships are positively allometric $(b>3)$ in males and negatively allometric $(b<3)$ in females. This agrees with the observations of Sanchez (1981), and Ch.M. Nigmatullin (personal communication, 1993) who found a negatively allometric length-weight relationship in females and a positive one in males.

Concerning Todaropsis eblanae, a wide range of sizes for mature males and females was observed. This range is wider than that observed by Mangold-Wirz (1963) in the Catalonian Sea. However, there was no size with $100 \%$ mature specimens. This could indicate individual variations at the maturation size rather than a continuous growth of the animals after complete maturation, as found by Harman et al. (1989) in 
Sthenoteuthis oualaniensis. The precocity of males in T. eblanae is in agreement with the observations of Mangold-Wirz (1963), Coelho and Borges (1982) and Joy (1989).

The spawning period of T. eblanae began in February-March, but further studies are necessary in order to test whether the spawning period of this species extends until October-November as found by Mangold-Wirz (1963) in the Mediterranean Sea and Burukovski et al. (1979) in the central-east Atlantic.

Males of T. eblanae were more abundant than females in Galician samples. The sex ratio found was very similar to that estimated by Mangold-Wirz (1963), but it was in disagreement with the observations of Joy (1989) in samples from Scottish trawlers. This divergence in results could be due to catch bias rather than to population structure.

The continuous presence of small specimens of T. eblanae (less than $100 \mathrm{~mm} \mathrm{ML}$ ) during the sampled period shows the existence of a constant recruitment from November to April, which agrees with that observed by Joy (1989) and Hastie et al. (1994).

As far as we know, the only published length-weight regression calculated for $\mathrm{T}$. eblanae was based on 88 South African specimens without distinguishing their sex (Cooper, 1979). The results obtained by Cooper (1979) were similar to those presented in this paper $(\mathrm{a}=0.11, \mathrm{~b}=2.67$; ML cm, BW g).

Although no distinction between I. coindetii and T. eblanae is made in the landing statistics obtained from the fishing markets, the decrease in landings of both ommastrephid squid between June and September, a fact repeated year after year, could have a biological explanation: I. coindetii and T. eblanae have similar spawning periods, with mature animals present within the population throughout the year. Both species probably have a single spawning peak in spring and early summer. If mature animals die after spawning, only a relatively small population of maturing and mature animals would be available in the fishing grounds during summer, while pre-recruits hatched in spring would not enter into the fishery until autumn. 
We thank M.T. Fernandez, F. Casas, B. Santos, F. Rocha, J. Alén and Dr. A.J. Figueras for their technical assistance and helpful criticism. M.R. would like to thank the Government of the Basque Country for grants which allowed his collaboration in this work. This work was funded by the Commission of the European Communities within the frame of this EEC research programme in the fisheries sector (FAR, contract no. MA. 1.146).

References

Burukovski, R.N., Gaevskaya, A.V., Domanevski, L.N., Nigmatulin, Ch.M. and Panfilov, B.G., 1979. Main results of research on squids carried out by the AtlantNIRO in the central-east Atlantic. ICES.C.M.1979/K, 2 pp.

Clarke, M.R., 1966. A review of the systematics and ecology of oceanic squids. Adv. Mar. Biol., 4: 91-300.

Coelho, M.L. and Borges, M.T., 1982. Preliminary results of research on squids, Loliginidae and Ommastrephidae, from the Portuguese coastal waters. ICES.C.M. 1982/K, 34 pp.

Cooper, J., 1979. Length-mass relationships, water content and energy values for two species of squid, Loligo reynaudii and Todaropsis eblanae, off the south-western cape. Fish. Bull. S. Afr., 11: 43-45.

Degner, E., 1925. Cephalopoda. Rep. Dan. Oceanogr. Exped. Med., 2: 1-94.

Gonzalez, A.F., Rasero, M. and Guerra, A., 1992. Evidence for a recent and sudden increase in the abundance of Illex coindetii (Cephalopoda: Ommastrephidae) off the Galician coast (NW Spain). In: F. Giusti and G. Manganelli (Editors), Abstr. 11th Int. Malacol. Congress, Siena, 1992. University of Siena, Siena, pp. 304-306.

Guerra, A., 1992. Mollusca, Cephalopoda. In: M.A. Ramos (Editor), Fauna Iberica, Vol. 1. Museo Nacional de Ciencias Naturales, CSIC, Madrid, 327 pp.

Harman, R.F., Young, R.E., Mangold, K.M., Suzuki, T. and Hixon, R.F., 1989. Evidence for multiple spawning in the tropical oceanic squid Sthenoteuthis oualaniensis (Teuthoidea: Ommastrephidae). Mar. Biol., 101: 513-519.

Hastie, L.C., Joy, J.B. and Pierce, G.J., 1994. Reproductive biology of Todaropsis eblanae (Cephalopoda: Ommastrephidae) in Scottish coastal waters. J. Mar. Biol. Assoc., UK, 74: 367-382. 
Jereb, P. and Ragonese, S., 1991. Distribution and reproductive biology of the squid Illex coindetii (Mollusca, Cephalopoda) in the Sicilian Channel. Bull. Mar. Sci., 49 (1/2): 664. (Abstr.)

Joy, J.B., 1989. The fishery biology ofommastrephid squid in Shetland waters. M. Sc.

Thesis, University of Aberdeen, UK, $118 \mathrm{pp}$.

Lipinski, M., 1979. Universal maturity scale for the commercially-important squids (Cepahlopoda: Teutoidea). The results of maturity classification of the lllex illecebrosus (LeSueur, 1821). Populations for the years 1973-1977. Res. Doc. Serial No. 5364, 79/II/38, ICNAF, 40 pp.

Lu, C.C., 1973. Systematics and Zoogeography of the squid genus Illex (Oegopsida:

Cephalopoda). Ph. D. Thesis, Memorial University, Newfoundland, Canada.

Lu, C.C., 1982. First record of Todaropsis eblanae (Ball, 1841) (Cephalopoda:

Oegopsida) in the Pacific Ocean. Venus (Jpn. J. Malac.), 41 (1): 67-70.

Mangoid-Wirz, K., 1963. Biologie des Cephalopodes bentiques et nectoniques de la Met Catalane. Vie Milieu, (Suppl.), 13: 285.

Nesis, K.N., 1979. Squids of the family Ommastrephidae in the Australian-New

Zealand region. In: Nekton and Ichthyoplankton of the Australian-New Zealand Region. Nauka, Moscow, pp. 140-146.

Nesis, K.N., 1987. Cephalopods of the World. T.F.H. Publications, Neptune City, USA, $351 \mathrm{pp}$.

Roper, C.F.E., Lu, C.C. and Mangold, K., 1969. A new species of 11 lex from the Western Atlantic and distributional aspects of other lllex species (Cephalopoda: Oegopsida). Proc. Biological Society of Washington. Vol. 82, pp. 295-322. Roper, C.F.E., Sweeney, M.J. and Nauen, C.E., 1984. FAO Species Catalogue. Vol. 3. Cephalopods of the World. An Annotated and Illustrated Catalogue of Species of Interest to Fisheries. Fish. Synop. No. 125, Vol. 3, FAO, Rome, 277 pp.

Sanchez, P., 1981. Caracteristicas bioecol6gicas de Illex coindetii (Vérany, 1837) en el Mar Catalan. Tesis Doctoral, Universidad de Barcelona, 219 pp.

Xunta de Galicia, 1993. Plan de Ordenacion de los Recursos Pesqueros y Marisqueros de Galicia. Xunta de Galicia, Santiago de Compostela, 880 pp. 
Fig. 1. Study area (Galician coast, northeastern Atlantic) showing the ports where samples were obtained.

Fig. 2. Monthly length frequency distributions of lllex coindetii

Fig. 3. Monthly length frequency distributions of Todaropsis eblanae

Fig. 4. Monthly landings of omrnastrephid squids for the period 1986-1991 in Galicia.

Fig. 5. Total annual landings and values of the catches of ommastrephid squids from 1980 to 1991 in Galicia. 1llex coindetii and Todaropsis eblanae are the only ommastrephid squid species significantly abundant in the Galician fishery.

Table 1

Percentage of I. coindetii males and females in each maturity stage and ML class

\begin{tabular}{|c|c|c|c|c|c|c|c|c|c|c|c|}
\hline \multirow[t]{2}{*}{ ML (mm) } & \multicolumn{5}{|c|}{ Males } & \multicolumn{6}{|c|}{ Females } \\
\hline & $1^{\mathrm{a}}$ & 2 & 3 & 4 & 5 & 1 & 2 & 3 & 4 & 5 & 6 \\
\hline $60-79$ & 100 & & & & & 100 & & & & & \\
\hline 80-99 & 99 & 0.4 & & 0.6 & & 100 & & & & & \\
\hline $100-119$ & 84.4 & 10.4 & 2.1 & 3.1 & & 100 & & & & & \\
\hline $120-139$ & 42.2 & 28.7 & 19.6 & 9.5 & & 95.0 & 5.0 & & & & \\
\hline $140-159$ & 5.1 & 17.6 & 31.6 & 45.7 & & 82.2 & 16.5 & 1.5 & 0.3 & 0.9 & \\
\hline $160-179$ & 0.3 & 3.1 & 11.1 & 85.5 & & 20.9 & 58.5 & 8.6 & 6.0 & 6.0 & \\
\hline 180-199 & & 1.8 & 1.8 & 96.4 & & 4.5 & 60.2 & 15.4 & 5.7 & 13.3 & 0.9 \\
\hline $200-219$ & & & 12.3 & 87.7 & & & 24.9 & 28.7 & 18.2 & 28.2 & \\
\hline $220-239$ & & & 2.8 & 97.2 & & & 12.1 & 23.9 & 22.0 & 42.0 & \\
\hline $240-259$ & & & & 100 & & & 5.9 & 16.6 & 23.1 & 51.1 & 2.9 \\
\hline $260-279$ & & & & 100 & & & & 11.1 & 36.1 & 47.2 & 5.6 \\
\hline $280-299$ & & & & & & & & 11.1 & 18.1 & 63.5 & 5.5 \\
\hline $300-319$ & & & & & & & & 8.3 & 8.3 & 75.0 & 8.4 \\
\hline $320-339$ & & & & & & & & & 10.0 & 80.0 & 10.0 \\
\hline $340-359$ & & & & & & & & & 60.0 & 20.0 & 20.0 \\
\hline $360-379$ & & & & & & & & & & 50.0 & 50.0 \\
\hline
\end{tabular}

${ }^{\mathrm{a}}$ Maturity stage. 
Table 2

Monthly percentage of I. coindetii males and females in each maturity stage Month Males Females

\begin{tabular}{lllllllllll}
\hline $1^{\mathrm{a}}$ & 2 & 3 & 4 & 5 & 1 & 2 & 3 & 4 & 5 & 6
\end{tabular}

$\begin{array}{lllllllllll}\text { Nov. } & 75.4 & 8.1 & 4.1 & 12.4 & 58.7 & 12.2 & 3.4 & 6.8 & 17.0 & 1.9\end{array}$

$\begin{array}{lllllllllll}\text { Dec. } & 43.7 & 18.5 & 13.9 & 23.9 & 61.2 & 24.3 & 3.9 & 5.1 & 4.7 & 0.8\end{array}$

$\begin{array}{llllllllll}\text { Jan. } & 56.4 & 11.7 & 9.8 & 22.1 & 68.5 & 18.1 & 6.1 & 2.8 & 4.5\end{array}$

$\begin{array}{llllllllll}\text { Feb. } & 48.0 & 15.8 & 11.3 & 24.9 & 77.1 & 16.9 & 3.9 & 1.5 & 1.5\end{array}$

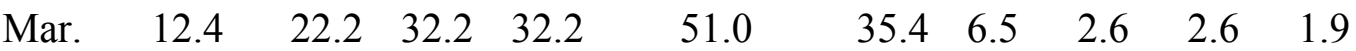

$\begin{array}{llllllllll}\text { Apr. } & 4.9 & 5.6 & 14.8 & 74.7 & 13.1 & 23.4 & 18.0 & 13.6 & 31.9\end{array}$

${ }^{\mathrm{a}}$ Maturity stage.

Table 3

Percentage of T. eblanae males and females in each maturity stage and ML class

\begin{tabular}{|c|c|c|c|c|c|c|c|c|c|c|c|c|}
\hline \multirow[t]{2}{*}{$\mathrm{ML}(\mathrm{mm})$} & \multicolumn{5}{|c|}{ Males } & \multirow[t]{2}{*}{$\overline{\mathrm{ML}}(\mathrm{mm})$} & \multicolumn{6}{|c|}{ Females } \\
\hline & $1^{\mathrm{a}}$ & 2 & 3 & 4 & 5 & & 1 & 2 & 3 & 4 & 5 & 6 \\
\hline $50-69$ & 100 & & & & & $40-59$ & 100 & & & & & \\
\hline $70-89$ & 95.2 & 4.8 & & & & $60-79$ & 100 & & & & & \\
\hline $90-109$ & 50.0 & 46.0 & 3.6 & 0.4 & & $80-99$ & 97.6 & 1.7 & 0.7 & & & \\
\hline $110-129$ & 3.5 & 61.0 & 22.7 & 12.0 & 0.8 & $100-119$ & 78.7 & 20.7 & 0.6 & & & \\
\hline $130-149$ & & 4.8 & 25.3 & 65.0 & 4.9 & $120-139$ & 41.5 & 48.8 & 9.7 & & & \\
\hline \multirow[t]{4}{*}{$150-169$} & & & 15.8 & 73.7 & 11.5 & $140-159$ & 4.2 & 45.8 & 45.8 & 4.2 & & \\
\hline & & & & & & $160-179$ & 6.6 & 13.4 & 40.0 & 20.0 & 20.0 & \\
\hline & & & & & & 180-199 & & 12.5 & 18.8 & 68.7 & & \\
\hline & & & & & & $200-219$ & & 10.0 & 10.0 & 80.0 & & \\
\hline
\end{tabular}

${ }^{\text {a }}$ Maturity stage.

Table 4

Monthly percentage of $\mathrm{T}$. eblanae males and females in each maturity stage

\begin{tabular}{llllllllllll}
\hline Month & \multicolumn{10}{c}{ Females } \\
& $1^{\mathrm{a}}$ & 2 & 3 & 4 & 5 & 1 & 2 & 3 & 4 & 5 & 6 \\
Nov. & 95.7 & 3.4 & & & 0.9 & 97.9 & & & & 2.1 & \\
Dec. & 64.5 & 34.8 & 0.7 & & & 84.5 & 12.0 & & & \\
Jan. & 35.7 & 43.7 & 18.8 & 1.8 & & 82.0 & 14.5 & 3.5 & & \\
\hline
\end{tabular}




\begin{tabular}{lllllllllll}
\hline Feb. & 43.7 & 32.0 & 11.6 & 12.7 & & 65.0 & 19.6 & 7.7 & 3.4 & 4.3 \\
Mar. & 31.6 & 40.7 & 11.5 & 15.7 & 0.5 & 55.9 & 25.8 & 5.3 & 1.0 & 12.0 \\
Apr. & 2.5 & 7.7 & 17.9 & 65.4 & 6.5 & 15.4 & 28.8 & 17.3 & 7.7 & 30.8 \\
\hline
\end{tabular}

${ }^{a}$ Maturity stage.

Table 5

lllex coindetii sex ratio and $\chi^{2}$ results

\begin{tabular}{lllllllll}
\hline & Nov. & Dec. & Jan. & Feb. & Mar. & Apr. & Total & Ratio \\
\hline Males & 118 & 288 & 278 & 242 & 263 & 242 & 1431 & 1.05 \\
Females & 151 & 223 & 253 & 255 & 237 & 240 & 1359 & 1.00 \\
& $*$ & $*$ & NS & NS & NS & NS & NS & \\
& & & & & & & &
\end{tabular}

* $\mathrm{P}<0.05 ; \mathrm{NS}$, not significant.

Table 6

Todaropsis eblanae sex ratio and $\chi^{2}$ result

Nov. Dec. Jan. Feb. Mar. Apr. Total Ratio

\begin{tabular}{lllllllll}
\hline Males & 117 & 158 & 105 & 112 & 114 & 78 & 684 & 1.18 \\
Females & 94 & 142 & 83 & 117 & 92 & 54 & 582 & 1.00 \\
& NS & NS & NS & NS & NS & $*$ & $*$ & \\
\hline
\end{tabular}

$* \mathrm{P}<0.05$; NS, not significant. 